\title{
Bankruptcy and the Market for Mortgage and Home Improvement Loans ${ }^{1}$
}

\author{
Emily Y. Lin \\ Department of Economics, University of Connecticut, 341 Mansfield Road, \\ U-63, Storrs, Connecticut 06269 \\ and \\ Michelle J. White \\ Department of Economics, University of California, San Diego, La Jolla, \\ California 92093-0508
}

Received November 2, 1999; revised December 7, 2000; published online May 24, 2001

This paper investigates the relationship between bankruptcy exemptions and the availability of credit for mortgage and home improvement loans. We develop a combined model of debtors' decisions to file for bankruptcy and to default on their mortgages and show that the theory predicts positive relationships between both the homestead and personal property exemption levels and the probability of borrowers being denied mortgage and unsecured loans. We test these predictions empirically and find strong and statistically significant support when evidence from cross-state variation in bankruptcy exemption levels is used. Applicants for mortgages are 2 percentage points more likely to be turned down for mortgages and 5 percentage points more likely to be turned down for home improvement loans if they live in states with unlimited rather than low homestead exemptions. These relationships also hold when we introduce state fixed effects into the model. (c) 2001 Academic Press

\section{INTRODUCTION}

The United States is extremely unusual in having very pro-debtor bankruptcy laws and, alone among the industrialized countries, it has a high and rapidly rising bankruptcy filing rate. The total number of bankruptcy filings has risen from under 300,000 per year in 1984 to 1.1 million in 1996 and 1.4 million in

${ }^{1}$ We are grateful to Jan Brueckner, Masaru Konishi, Kenya Fujiwara, and the referee for very helpful comments. An earlier version of this paper was presented at the 36th Econometrics Conference held at Lake Biwa, Japan, July 1998. Research support was provided by the Law and Social Science and Economics Programs at the National Science Foundation, under Grant SBR9617712. 
1998. ${ }^{2}$ The rapid increase in bankruptcy filings has led researchers to explore how bankruptcy affects consumers' access to credit.

When debtors in the United States file for personal bankruptcy, many types of debts are discharged, causing losses for creditors. Debtors who file under Chapter 7 of the U.S. Bankruptcy Code are not obliged to use future income to repay their debts and are only obliged to use wealth to repay debt to the extent that their wealth exceeds predetermined exemption levels. Exemption levels in bankruptcy are set by the state in which the debtor lives and they vary widely. They therefore may affect the terms on which loans are made. In a recent article, Gropp et al. [12] argued that in states with high rather than low bankruptcy exemptions, demand for credit rises because debtors' wealth is more sheltered from the consequences of financial distress and supply of credit falls because debtors are more likely to default and file for bankruptcy. They found empirical support for these predictions.

However, Berkowitz and Hynes [2] (hereinafter B-H) recently argued that these conclusions do not hold up when the analysis distinguishes between different types of debts and different types of exemptions. Bankruptcy law distinguishes between secured versus unsecured debts. Secured (collateralized) debts - such as mortgages and automobile loans - allow the creditor to reclaim the collateral if the debtor defaults on the loan, while unsecured debts - such as credit card and installment loans - have no collateral. Because secured creditors can foreclose on their collateral when debtors default, regardless of whether debtors file for bankruptcy, they are in a much stronger position than unsecured creditors to collect. States also provide separate exemptions for equity in owner-occupied homes (homestead exemptions) versus other types of property (personal property exemptions). B-H argue that higher homestead exemptions in bankruptcy help rather than harm secured creditors and therefore increase the supply of credit. Their argument is that, when debtors are in financial distress, they can file for bankruptcy, obtain discharge of their nonmortgage debts, and use the funds that would otherwise go to nonmortgage creditors to repay their mortgages and thereby keep their homes. The higher the exemptions, the more that debtors' wealth is protected in bankruptcy and therefore the lower the probability that they will default on their mortgages.

Our goal in this paper is to re-examine the effect of bankruptcy on supply and demand for credit, distinguishing between secured versus unsecured credit and between homestead versus personal property exemptions. In Section 2, we analyze debtors' decisions to default on their mortgages and to file for bankruptcy and the effect of both types of bankruptcy exemptions on the supply and demand for credit. Our theoretical model does not support B-H's claim that higher bankruptcy exemptions increase the supply of secured credit. Instead the

\footnotetext{
${ }^{2}$ Bankruptcy filing data are taken from the Administrative Office of the U.S. Courts and from the Statistical Abstract of the United States, various editions.
} 
model predicts that higher exemption levels cause lenders to tighten credit rationing, especially when exemption levels are already high. In Section 3 and 4, we test the model using data from 1992-97 on both mortgage and home improvement loans from the Home Mortgage Disclosure Act (HMDA) dataset. We find that debtors are significantly more likely to be denied both home purchase and home improvement loans when they live in states with higher bankruptcy exemptions. We find support for these relationships using both cross-section variation in bankruptcy exemption levels and changes in bankruptcy exemptions over time.

\section{THEORY}

In this section we develop a model which integrates consumers' decisions to default on their mortgages with their decisions to file for bankruptcy. There is a large literature on mortgage default and our model does not attempt to advance that literature. Instead we focus on examining the interaction between the two decisions. ${ }^{3}$

The model has two periods. In period 1, a representative consumer has an exogenously determined level of nonhousing wealth $w$, which includes his or her period 1 income, his or her period 1 financial wealth, and the value of any nonfinancial wealth he or she owns other than the house that serves as the primary residence. The consumer buys a house of value $v$, financed by a mortgage of amount $M$ which is secured by the house. The consumer also borrows an amount $P$ on an unsecured basis. By assumption, the consumer has only one unsecured loan. ${ }^{4}$ The interest rates are $r_{m}$ on the mortgage and $r_{p}$ on the unsecured loan. In period 2, both loans come due, so that the consumer owes $M^{\prime}=M\left(1+r_{m}\right)$ on the mortgage and $P^{\prime}=P\left(1+r_{p}\right)$ on the unsecured loan. The consumer's nonhousing wealth in period 2 , including period 2

\footnotetext{
${ }^{3}$ Although the mortgage default and bankruptcy decision literatures have developed separately, they are strikingly similar. Both decisions are "ruthless" in that the value of defaulting or filing for bankruptcy depends only on the value of particular assets or liabilities. Whether mortgage default is worthwhile depends only on the value of housing equity and the value of nonhousing wealth relative to the personal property exemption; whether bankruptcy is worthwhile depends only on the value of dischargeable debt compared to nonexempt assets. However, both decisions have been shown to be less ruthless in fact than in theory, presumably because both have transactions costs and lead to credit impairment and loss of reputation. Quigley and Van Order [17] and Capozza et al. [7] show that default decisions are not ruthless because other household characteristics besides housing equity are significant determinants of default; Fay et al. [10] show that bankruptcy filing decisions are not ruthless because demographic characteristics and income are significant determinants of the bankruptcy decision. Both decisions have also been modelled assuming that borrowers have private information concerning their propensities to default/file for bankruptcy. See Brueckner $[4,5]$ for asymmetric information models of the mortgage default decision and Wang and White [20] and Adler et al. [1] for asymmetric information models of the bankruptcy decision.

${ }^{4}$ See Bizer and De Marzo [3] for discussion of how creditors' incentives are affected by whether debtors have prior loans.
} 
income, is denoted $W . W$ is uncertain and has the known density function $f(W)$. The value of the debtor's house in period 2 is $V . V$ is also uncertain and has the known distribution function $g(V) . f(W)$ and $g(V)$ may be either independent or correlated. ${ }^{5}$

\section{A. Borrowers' Behavior}

After learning $W$ and $V$ at the beginning of period 2, the consumer decides whether to default on the unsecured loan and whether to default on the mortgage. If the consumer defaults on the unsecured loan, then he or she is assumed to file for bankruptcy. When consumers file for bankruptcy, their unsecured debt is discharged, but their mortgage debt is not. ${ }^{6}$ The obligation to repay debt in bankruptcy is determined by the bankruptcy exemption in the consumer's state of residence. Each state has two types of exemptions, one for equity in housing-denoted $E_{h}$ - and one for all other types of property-denoted $E_{p}{ }^{7}$ The consumer must give up nonhousing wealth in excess of $E_{p}$ and this amount is used to repay unsecured creditors. Also, the consumer must give up his or her house in bankruptcy if the home equity exceeds the homestead exemption $E_{h}$. If home equity is less than the homestead exemption and if the consumer has not defaulted on the mortgage, then the consumer can keep the house when he or she files for bankruptcy. Consumers' out-of-pocket costs of filing for bankruptcy-including filing fees and lawyers' fees-are denoted $C_{b}$. We assume that $C_{b}$ must be paid before filing for bankruptcy-for obvious reasons, bankruptcy lawyers do not offer credit!

If the consumer defaults on the mortgage and does not cure the default by repaying the amount owed within several months, then the mortgage lender will foreclose on the house. When foreclosure occurs, the consumer must relocate to a new residence at a cost of $R$. After foreclosure, the mortgage lender sells the house for an amount $V-C_{f}$, where $C_{f}$ is the transactions cost of foreclosure. ${ }^{8}$ The proceeds of selling the house are used, first, to pay the costs of foreclosure $C_{f}$ and, second, to repay the mortgage and then the second mortgage-if

\footnotetext{
${ }^{5}$ Whether $f(W)$ and $g(V)$ are independent or not affects the probabilities that the various cases discussed below occur. Using data from the PSID Wealth Supplements for 1984 and 1989, the correlation between $f(W)$ and $g(V)$ is only 0.27 .

${ }^{6}$ This discussion assumes that consumers file for bankruptcy under Chapter 7 of the U.S. Bankruptcy Code. About $70 \%$ of bankruptcy filings in the United States are under Chapter 7. Consumers who file under Chapter $13 \mathrm{keep}$ all their assets but must propose a plan to repay part of their debts from future income. Since consumers have the right to choose between the two chapters, they cannot be forced to repay more under Chapter 13 than under Chapter 7. We therefore assume that repayment under Chapter 13 would be about the same as under Chapter 7 and we ignore Chapter 13 in the discussion that follows. See White [21] for discussion.

${ }^{7}$ States normally adopt separate exemptions for several types of personal property, such as cash, equity in vehicles, clothing, and household effects. $E_{p}$ equals the sum of these exemptions.

${ }^{8} C_{f}$ includes the cost of additional wear and tear by owners who anticipate defaulting on their mortgages.
} 
any-in full. (In the empirical work, we examine home improvement loans, which often take the form of second mortgages.) Third, an amount up to the homestead exemption $E_{h}$ is returned to the consumer. Fourth, the remainder is used to repay unsecured debt. In most foreclosures, the proceeds of selling the house are less than the amount owed on the mortgage, or $V-C_{f}<M^{\prime}$. For simplicity, we assume that mortgage lenders do not have the right to collect deficiency judgments from debtors, so that they lose whatever portion of the mortgage is not covered by the proceeds of foreclosure. ${ }^{9}$

When the consumer both defaults on the mortgage and files for bankruptcy, the mortgage lender is assumed to incur additional transactions costs of $D$. We expect that $D$ is positive, since foreclosure in the context of bankruptcy requires approval of the bankruptcy trustee and is therefore likely to be delayed. However, $D$ could alternatively be zero, if bankruptcy has no effect on the speed or uncertainty of foreclosure. Our empirical work provides evidence concerning $D$.

Since both $V$ and $W$ are uncertain, there are a range of possible cases, corresponding to varying levels of $V$ and $W$. We divide the distribution of housing values into four regions and discuss them in order of lowest to highest.

Case (A). $V<M^{\prime}-R$. Here, housing value is so low that home equity $V-M^{\prime}$ is more negative than the cost of relocation, $-R$.

First consider the consumer's decision to default on the mortgage. If he or she does not file for bankruptcy and does not default, then his or her total net housing plus nonhousing wealth will be $W-P^{\prime}+V-M^{\prime}$. If he or she does not file for bankruptcy but defaults, then his or her total net wealth will be $W-P^{\prime}-R$. Since $V<M^{\prime}-R$, the debtor has an incentive to default. Now suppose the consumer does not default but files for bankruptcy. Then the total net wealth will be either $V-M^{\prime}+W-C_{b}$ or $V-M^{\prime}+E_{p}$, whichever is lower. Finally if the consumer files for bankruptcy and defaults, then the total net wealth will be either $-R+W-C_{b}$ or $-R+E_{p}$, whichever is lower. Since $V<M^{\prime}-R$, the consumer again has an incentive to default. Therefore the consumer's decision to default on the mortgage is independent of his or her nonhousing wealth $W .^{10}$

Now consider the consumer's bankruptcy decision, assuming that he or she defaults on the mortgage. There is a threshold level of nonhousing wealth in Case (A), denoted $\tilde{W}_{A}$, where the consumer is indifferent between filing versus not filing for bankruptcy. If $W$ is just below $\tilde{W}_{A}$, then he or she files for bankruptcy and the non-housing wealth becomes $E_{p}$. If $W>\tilde{W}_{A}$, then he or

\footnotetext{
${ }^{9}$ It is straightforward to modify the analysis of Cases (A) and (B) below to allow for deficiency judgments. Note that the foreclosure $\cos t C_{f}$ is borne by whatever party is the last to be paid.

${ }^{10}$ This model of the default decision is obviously simplified. With more time periods, the borrower might choose not to default on the mortgage even if $V<M^{\prime}-R$, if he or she expected housing values to rise in the future.
} 
she does not file for bankruptcy and the nonhousing wealth becomes $W-P^{\prime}$. This means that $\tilde{W}_{A}=E_{p}+P^{\prime}$. The consumer files for bankruptcy if $W \leq \tilde{W}_{A}$ and avoids bankruptcy otherwise.

Figure 1 shows nonhousing wealth $W$ on the horizontal axis and total net housing plus nonhousing wealth after debt repayment, default, and/or bankruptcy, on the vertical axis. The curve labelled Case (A) has three segments. In the left-most segment, consumers file for bankruptcy and, because $W \leq E_{p}+C_{b}$, their total net wealth is $W-C_{b}-R$. In the middle (flat) segment, $E_{p}+C_{b}<W \leq \tilde{W}_{A}$. Consumers file for bankruptcy and their total net wealth is $E_{p}-R$. In the right-most segment, consumers avoid bankruptcy and their total net wealth is $W-P^{\prime}-R$. Table 1 shows repayment to mortgage and unsecured creditors in Case (A). Because consumers always default on their mortgages, mortgage lenders receive either $V-C_{f}$ or $V-C_{f}$ $-D$, depending on whether consumers file for bankruptcy. Unsecured creditors receive full repayment of $P^{\prime}$ if $W \geq \tilde{W}_{A}$, partial repayment of $W-E_{p}-C_{b}$ if $E_{p}+C_{b} \leq W<\tilde{W}_{A}$, and nothing if $W<E_{p}+C_{b}$.

Case (B). $\quad-R \leq V-M^{\prime} \leq E_{h}+C_{f}$ and $E_{p} \geq M^{\prime}$. Here, housing value is high enough that home equity exceeds the cost of relocation. The consumer would therefore like to repay the mortgage and retain his or her house. But depending on the realization of $W$ and the personal property exemption level, he or she may or may not have enough wealth to do so. B-H pointed out that

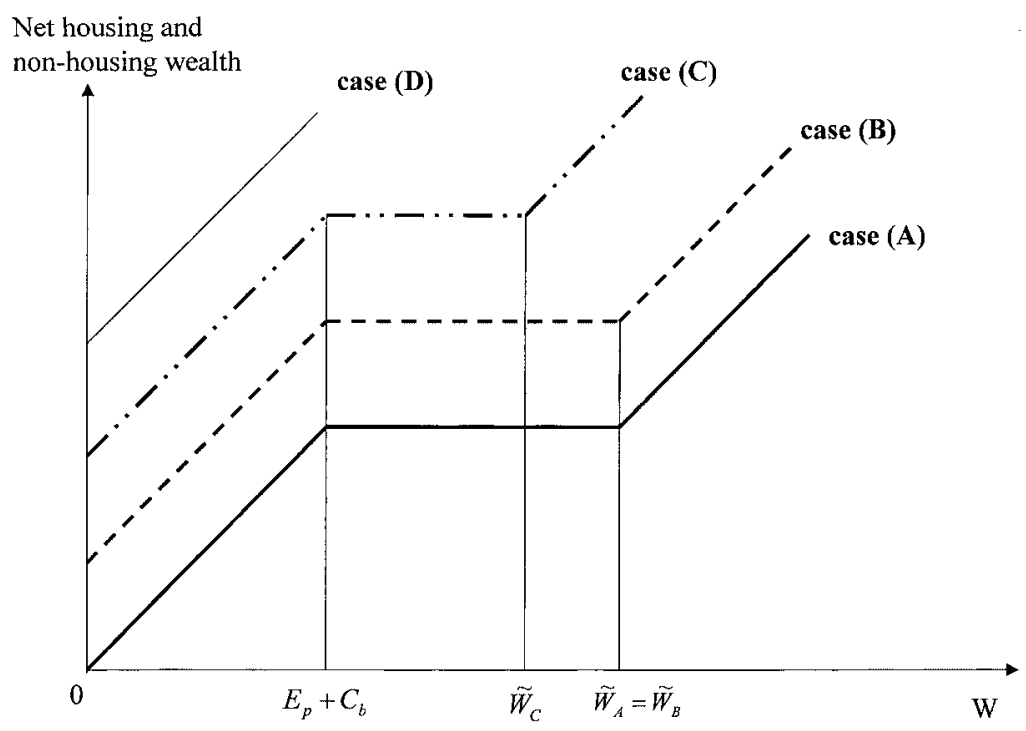

FIGURE 1 
TABLE 1

Amounts Paid to Mortgage and Unsecured Creditors

\begin{tabular}{lllll}
\hline Nonhousing wealth & $\begin{array}{c}\text { Action } \\
\text { by } \\
\text { debtor }\end{array}$ & $\begin{array}{c}\text { Amount } \\
\text { paid to } \\
\text { mortgage } \\
\text { creditor }\end{array}$ & $\begin{array}{c}\text { Amount paid to } \\
\text { unsecured creditor }\end{array}$ & $\begin{array}{c}\text { Debtors' total } \\
\text { net wealth }\end{array}$ \\
\hline \multicolumn{5}{c}{ Case (A): $V \leq M^{\prime}-R$} \\
\hline$W_{\min } \leq W \leq E_{p}+C_{b}$ & $\mathrm{D} / \mathrm{B}$ & $V-C_{f}-D$ & 0 & $W-C_{b}-R$ \\
$E_{p}+C_{b} \leq W \leq \tilde{W}_{A}$ & $\mathrm{D} / \mathrm{B}$ & $V-C_{f}-D$ & $W-E_{p}-C_{b}$ & $E_{p}-R$ \\
$\tilde{W}_{A} \leq W \leq W_{\max }$ & $\mathrm{D}$ & $V-C_{f}$ & $P^{\prime}$ & $W-P^{\prime}-R$ \\
\hline
\end{tabular}

Case (B): $M^{\prime}-R<V \leq M^{\prime}+E_{h}+C_{f}$ and $E_{p}>M^{\prime}$

\begin{tabular}{lllll}
\hline$W_{\min } \leq W \leq M^{\prime}+C_{b}$ & $\mathrm{D} / \mathrm{B}$ & $V-C_{f}-D$ & 0 & $W-C_{b}-R$ \\
$M^{\prime}+C_{b}<W \leq E_{p}+C_{b}$ & $\mathrm{~B}$ & $M^{\prime}-D$ & 0 & $W-C_{b}+V-M^{\prime}$ \\
$E_{p}+C_{b}<W \leq \tilde{W}_{B}$ & $\mathrm{~B}$ & $M^{\prime}-D$ & $W-E_{p}-C_{b}$ & $E_{p}+V-M^{\prime}$ \\
$\tilde{W}_{B}<W \leq W_{\max }$ & None & $M^{\prime}$ & $P^{\prime}$ & $W-P^{\prime}+V-M^{\prime}$ \\
\hline
\end{tabular}

Case (C): $M^{\prime}+E_{h}+C_{f}<V \leq M^{\prime}+E_{h}+P^{\prime}+C_{f}$

\begin{tabular}{lllll}
\hline$W_{\min } \leq W \leq E_{p}+C_{b}$ & B & $M^{\prime}-D$ & $V-C_{f}-M^{\prime}-E_{h}$ & $W-C_{b}-R$ \\
$E_{p}+C_{b}<W \leq \tilde{W}_{C}$ & $\mathrm{~B}$ & $M^{\prime}-D$ & $W-E_{p}-C_{b}$ & $E_{p}+E_{h}-R$ \\
& & & $+V-C_{f}-M^{\prime}-E_{h}$ & \\
$\tilde{W}_{C}<W \leq W_{\max }$ & None & $M^{\prime}$ & $P^{\prime}$ & $W-P^{\prime}+V-M^{\prime}$ \\
\hline
\end{tabular}

Case (D): $V>M^{\prime}+E_{h}+P^{\prime}+C_{f}$

\begin{tabular}{|c|c|c|c|c|}
\hline$W_{\min } \leq W \leq W_{\max }$ & None & $M^{\prime}$ & $P^{\prime}$ & $W-P^{\prime}+V-M^{\prime}$ \\
\hline
\end{tabular}

Notes. $M^{\prime}=M\left(1+r_{m}\right), P^{\prime}=P\left(1+r_{p}\right), \quad \tilde{W}_{A}=E_{p}+P^{\prime}, \quad \tilde{W}_{A}=\tilde{W}_{B}$, and $\tilde{W}_{C}=\tilde{W}_{A}-V+$ $M^{\prime}+E_{h}-R$. D, default; B, bankruptcy.

filing for bankruptcy increases the consumer's wealth by reducing the amount that he or she must repay to unsecured creditors and this positive wealth effect increases the consumer's ability to repay the mortgage. To explore this possibility, we assume that consumers use up to $100 \%$ of their nonhousing wealth to repay their mortgages. We also assume that the personal property exemption exceeds the mortgage debt, or $E_{p} \geq M^{\prime}$. This assumption is unrealistic in that most states' personal property exemptions are much smaller than a typical mortgage loan. However, the amount past due on a mortgage loan may be much smaller than the principal amount and therefore less than $E_{p}$. This assumption also allows us to examine the B-H claim in the most favorable circumstances. ${ }^{11}$

\footnotetext{
${ }^{11}$ Data on personal property exemptions is given below. We assume again that deficiency judgments are prohibited.
} 
First consider the consumer's bankruptcy decision, assuming that he or she does not default on the mortgage. Suppose $\tilde{W}_{B}$ is now the threshold level of nonhousing wealth in Case (B) such that the consumer is indifferent between filing versus not filing for bankruptcy. He or she keeps total net wealth of $E_{p}+V-M^{\prime}$ if filing for bankruptcy and $W-P^{\prime}+V-M^{\prime}$ if not. Therefore $\tilde{W}_{B}=E_{p}+P^{\prime}$, so that $\tilde{W}_{B}=\tilde{W}_{A}$. If consumers' nonhousing wealth is below $\tilde{W}_{B}$, then they file for bankruptcy and, if possible, repay their mortgages. However, if $W$ turns out to be sufficiently low, then consumers cannot repay their mortgages even after filing for bankruptcy and devoting all of their nonhousing wealth to mortgage repayment. The minimum level of wealth at which consumers can just afford to repay their mortgages after filing for bankruptcy is $W=C_{b}+M^{\prime}$. Consumers therefore default on their mortgages if $W<C_{b}+M^{\prime}$. Table 1 shows that mortgage lenders receive $M^{\prime}$ if $W>$ $\tilde{W}_{B}, M^{\prime}-D$ if $M^{\prime}+C_{b} \leq W \leq \tilde{W}_{B}$, and $V-C_{f}-D$ if $W<M^{\prime}+C_{b}$. Unsecured lenders receive $P^{\prime}$ if $W \geq \tilde{W}_{B}, W-E_{p}-C_{b}$ if $E_{p}+C_{b} \leq W<$ $\tilde{W}_{B}$, and 0 if $W<E_{p}+C_{b}$. The line labelled Case (B) in Fig. 1 shows that consumers have higher nonhousing wealth in Case (B) than case (A) but are equally likely to file for bankruptcy.

Case (B) thus illustrates the B-H hypothesis that consumers may file for bankruptcy in order to have their unsecured debt discharged and then use the wealth gain to repay their mortgages. This case may be unlikely in practice, however, since personal property exemptions in most states are low. ${ }^{12}$

Case $(C) . \quad E_{h}+C_{f}<V-M^{\prime} \leq E_{h}+P^{\prime}+C_{f}$. Here home equity exceeds the homestead exemption plus the cost of foreclosure, but it is less than the homestead exemption plus the unsecured debt. The consumer has relatively high housing equity but may have large unsecured debts - perhaps because he or she owns an unincorporated business. The unsecured creditor may therefore find it worthwhile to foreclose on the house if the consumer defaults on the unsecured loan and files for bankruptcy. ${ }^{13}$ If the consumer files for bankruptcy and the unsecured creditor forecloses, the house is sold for $V-C_{f}$, the mortgage lender receives $M^{\prime}$, and the consumer receives $E_{h}$. The remaining amount, $V-C_{f}-M^{\prime}-E_{h}$, goes to the unsecured creditor. Because the unsecured creditor forecloses on the house when bankruptcy occurs, the decisions to default on the mortgage and file for bankruptcy are tied: the consumer either defaults on both loans or repays both. If he or she defaults and files for bankruptcy, the nonhousing wealth is $E_{h}+E_{p}-R$ and if he or she repays both loans, the nonhousing wealth is $W-P^{\prime}+V-M^{\prime}$. The level of nonhousing wealth at which he or she is indifferent between these alternatives, denoted $\tilde{W}_{C}$, is therefore $\tilde{W}_{C}=\tilde{W}_{A}-V+M^{\prime}+E_{h}-R$. Since under reason-

\footnotetext{
${ }^{12}$ If $E_{p}<M^{\prime}$, then it is straightforward to show that consumers would be less likely to file for bankruptcy, but more likely to default on their mortgages.

${ }^{13}$ See Steingold [18, pp. 21/2-4].
} 
able parameter values, $\tilde{W}_{C}<\tilde{W}_{A}$, the debtor is less likely to file for bankruptcy in Case (C) than in Cases (A) or (B). Figure 1 shows the debtor's net housing plus nonhousing wealth in Case (C) and Table 1 shows repayment to lenders.

Case (D). $V-C_{f}-M^{\prime}>E_{h}+P^{\prime}$. Because $V$ is high, the consumer never defaults on the mortgage and never files for bankruptcy. If the nonhousing wealth turns out to be too low to repay the unsecured loan, then he or she sells the house and uses the proceeds to repay both the mortgage and the unsecured loans in full. ${ }^{14}$

\section{B. Lenders' Behavior}

Both mortgage and unsecured lenders are assumed to receive loan applications from many potential borrowers, all of whom are identical as of period 1 . Both types of lenders are risk neutral, so they are willing to lend if expected repayment covers their fixed opportunity cost of funds.

Now suppose one of the bankruptcy exemption levels increases and the probability of default on one or both types of loans therefore rises. Do lenders respond by raising the interest rate or rationing credit or a combination of both? Most economists tend to assume that, when all information is common knowledge, lenders always respond to a change which causes the probability of default to rise by raising the interest rate. Conversely they tend to assume that, when there is asymmetric information, lenders respond to a change which causes the probability of default to rise by rationing credit. However, asymmetric information is not a necessary condition for credit rationing. In our context, suppose an increase $E_{p}$ or $E_{h}$ causes the default rate on mortgage loans to rise. If lenders respond by raising mortgage interest rates, then borrowers repay more when they do not default. But the rise in the interest rate causes an additional increase in the probability of default above and beyond the increase caused by the rise in the exemption level. This means that raising the interest rate has both a positive and a negative effect on expected repayment. If the probability of default is low, then the positive effect outweighs the negative effect and raising the interest rate therefore causes expected repayment to rise. But if the probability of default is sufficiently high, then the reverse holds and raising the interest rate causes expected repayment to fall. In the latter situation, lenders would respond to the original change by tightening credit rationing rather than raising the interest rate. Thus any change that reduces expected repayment on loans may cause lenders either to raise the interest rate or to ration credit. More specifically, the model also implies that the relationship between the probability of credit rationing and the exemption level is nonlinear

\footnotetext{
${ }^{14}$ Note that if the homestead exemption is unlimited, as it is in seven states, then neither Case (C) nor (D) can occur.
} 
- the marginal effect of an increase in the exemption level increases as the exemption level rises. ${ }^{15}$

Now consider how changes in the bankruptcy exemption levels $E_{p}$ and $E_{h}$ affect expected repayment on mortgage and unsecured loans. To start with, assume that the $D=0$; i.e., the cost of foreclosure is unaffected by whether borrowers file for bankruptcy. Under these assumptions, neither the homestead exemption nor the personal property exemption affects the terms on which mortgage lenders are willing to lend. Table 1 shows that mortgage lenders always receive partial repayment of $V-C_{f}$ in Case (A), and they always receive full repayment of $M^{\prime}$ in Cases (C) and (D). In Case (B), they may receive either partial or full repayment, but the condition under which partial versus full repayment occurs (whether $W$ is greater than or less than $M^{\prime}+C_{b}$ ) is independent of the exemption levels. Thus neither a change in $E_{h}$ nor $E_{p}$ is predicted to affect the terms of mortgage loans. When debtors default on their mortgages, mortgage lenders are repaid only from the proceeds of foreclosure and their claims rank above the exemption. So repayment is independent of the values of both $E_{p}$ and $E_{h}$.

Now suppose $D>0$, but all other assumptions remain the same. Because mortgage lenders pay costs of $D$ when borrowers file for bankruptcy, expected repayment now depends negatively on the probability of bankruptcy. When $E_{p}$ rises, the probability of bankruptcy rises in Cases (A), (B), and (C), because $\tilde{W}_{A}, \tilde{W}_{B}$, and $\tilde{W}_{C}$ all depend positively on $E_{p}$. Also, the probability of Cases (A), (B), and (C) occurring remains the same. Thus a rise in $E_{p}$ causes lenders to tighten the terms of mortgage loans. Now consider a rise in $E_{h}$. A rise in $E_{h}$ causes the probability of bankruptcy to increase in Case (C), because $\tilde{W}_{C}$ depends positively on $E_{h}$. In addition, a rise in $E_{h}$ makes Case (D) less likely to occur and also makes Case (B) more likely to occur. Since the probability of bankruptcy is higher in Case (C) than Case (D) and higher in Case (B) than Case (C), both changes reduce expected repayment to mortgage lenders because

${ }^{15}$ As an example of credit rationing when all information is common knowledge, suppose there is no legal distinction between housing versus nonhousing wealth or between mortgage loans versus unsecured loans. Suppose all borrowers borrow $\$ 1000$ in period 1 and their period 2 wealth is distributed normally with a mean of $\$ 2000$ and a standard deviation of $\$ 250$. Also suppose the cost of bankruptcy is zero and lenders' opportunity cost of funds is 0.1 per period. If the bankruptcy exemption $E$ is less than $\$ 900$, lenders respond to an increase in $E$ by raising the interest rate. When $E \geq \$ 900$, lenders respond to an increase in $E$ by rationing credit completely (refusing to lend). Thus, in this example, credit rationing takes an all-or-nothing form. However, if borrowers differ according to some commonly observed characteristic related to the probability of default-such as income - then credit rationing will occur more gradually as $E$ rises. This is because lenders cease lending to low income borrowers at a low level of $E$ and cease lending to high income borrowers at a higher level of E. See Fan and White [9], Stiglitz and Weiss [19] developed the original model of credit rationing under asymmetric information. In their model, lenders respond to a change which raises the default rate by rationing some borrowers but lending to others. 
lenders are more likely to incur the additional delay costs $D$. Thus when costs $D$ are positive, a rise in either $E_{h}$ or $E_{p}$ reduces mortgage lenders' expected return and is predicted to cause the terms of mortgage loans to tighten. This is because lenders bear additional costs when borrowers file for bankruptcy, and increases in either exemption level make bankruptcy more likely. Even when borrowers use all available funds to avoid losing their homes, an increase in the either of the exemption levels is predicted to cause increased credit rationing on mortgage loans.

Now consider how changes in $E_{h}$ or $E_{p}$ affect expected repayment of unsecured loans. When $E_{h}$ rises, Table 1 shows that expected repayment of unsecured loans falls in Case (C), because repayment is lower when borrowers file for bankruptcy and the probability of bankruptcy rises. Expected repayment remains unaffected in all of the other cases. When $E_{p}$ rises, Table 1 shows that expected repayment of unsecured loans falls in all cases except Case (D), while the probability of being in Case (D) remains the same. Thus the model predicts that increases in both $E_{h}$ and $E_{p}$ unambiguously reduce expected repayment of unsecured loans. These results reflect the fact that lenders must collect from debtors' housing or nonhousing wealth, but their claims rank below the homestead and personal property exemptions. These results remain the same regardless of whether $D$ is zero or positive.

To sum up, the model predicts that an increase in either the homestead or the personal property exemption causes expected repayment of mortgage and unsecured loans to fall, as long as delay costs in bankruptcy $D$ are positive. These predictions hold even if we assume that borrowers file for bankruptcy to obtain discharge of their unsecured debt and use the entire wealth gain to repay their mortgages. The model also predicts that the marginal effect of an increase in either exemption level on the probability that lenders ration credit (rather than increasing the interest rate) rises as the exemption level increases. We test these predictions in the next section, using evidence of credit rationing on mortgage and home improvement loan applications.

\section{DATA AND EMPIRICAL SPECIFICATION}

We use the Home Mortgage Disclosure Act (HMDA) data for 1992 through 1997. This dataset contains information on a large number of applications for home purchase loans and home improvement loans. ${ }^{16}$ Home purchase loans (mortgages) are always secured by the house and always have highest priority for repayment if the house is sold in a foreclosure. Home improvement loans may be used for home improvements or other expenditures and may either be

\footnotetext{
${ }^{16}$ See Canner and Passmore [6] for a general description. The data have mainly been used to analyze discrimination in lending to low-income and minority households. See, for example, the articles in Yezer [22].
} 
unsecured or secured as second mortgages. ${ }^{17}$ The dataset does not indicate whether individual home improvement loan observations are secured or unsecured. Because home improvement loans rank below mortgages in priority, they are less completely secured, even if they take the form of second mortgages. Lenders therefore are forced to rely more heavily on debtors' nonhousing wealth for repayment. As a result, home improvement loans are a mixture of secured and unsecured, so they allow us to test the predictions of the model for unsecured loans. ${ }^{18}$

Our sample of both types of loans consists of all loan applications from the largest metropolitan area in each state. ${ }^{19} \mathrm{We}$ exclude applications that were withdrawn, closed for incompleteness, or purchased by an institution. For home purchase loan applications, we limit our sample to applications for loans used to purchase (rather than refinance) owner-occupied homes. Because sample sizes are large, we draw a 5\% random sample of home purchase loan applications and a $10 \%$ random sample of home improvement loan applications.

The HMDA data include information on whether the loan application was turned down and the applicant's state of residence, but only a few additional variables. We include dummies for the applicant's sex, whether the applicant is African-American, and whether there was a coapplicant for the loan, as well as the applicant's income (in thousands) and income squared. As an indicator of high risk, we also include a dummy variable which equals one if the loan amount applied for divided by the applicant's income is greater than three. ${ }^{20}$ To augment the sparse demographic information in the HMDA data, we merge it with census tract (neighborhood) information from the 1990 U.S. Census of Population and Housing. This allows us to include the median house value in the census tract where the house is located, the percent of houses in the census tract which are single family, and the percent of residents in the census tract who are African-American. We also include several state-level variables as controls for local macroeconomic conditions. These are the state's unemployment rate, the change in the average income level in the state since the previous year, and the aggregate bankruptcy filing rate per 1000 population in the

\footnotetext{
${ }^{17}$ The legal definition of home improvement loans requires either that the proceeds of the loan be used for repairs/improvements to the house or that the loan be secured by the house. (See 12 C.F.R. 203.)

${ }^{18}$ B-H also used the HMDA data, but they analyzed only home purchase loans and they used data from 1990-95. The HMDA home improvement data have not previously been analyzed. Note that some debtors have an incentive to make their home improvement loans secured, since doing so makes the interest payments deductable from taxable income for borrowers who itemize on their tax returns. But only about half of all homeowners itemize.

${ }^{19}$ See below for a test of whether this sample is representative.

${ }^{20}$ Omitting this variable from the regressions does not change the results for the exemption variables.
} 
applicant's state of residence during the previous year. Creditors are assumed to use last year's bankruptcy filing rate in the state to predict future default rates by residents of the state. A higher bankruptcy filing rate last year causes creditors to raise their prediction of next year's default probability and thus to reduce credit availability in the state. (See Fay et al. [10] for discussion.)

We also add information concerning the homestead and personal property exemptions in each consumer's state of residence. The personal property exemption is defined to be the sum of states' exemptions for personal property and equity in vehicles and their "wildcard" exemptions, which can be applied to any type of property. Most states have low personal property exemptions, but homestead exemptions vary widely, from zero in two states to unlimited in eight states. ${ }^{21}$ About one-third of the states also allow their residents to choose between a uniform Federal bankruptcy exemption and the state's exemption. In these states, we assign the highest of the two exemption values. Many states also allow married couples who file for bankruptcy to take higher exemptions, usually double. Because the dataset does not include information concerning marital status but does indicate whether there was a coapplicant for the loan, we assume that coapplicants are actually married couples and we double (or otherwise raise) the exemptions for coapplicants who live in states that allow doubling. We divide the homestead exemption into four categories and use dummy variables for each category above the lowest. This specification allows us to test the theoretical hypothesis that the marginal effect of an increase in the exemption level rises as the exemption level increases. The median homestead exemption values in the three lowest categories are $\$ 7500, \$ 15,000$, and $\$ 75,000$. The highest category consists entirely of unlimited homestead exemptions. Because the personal property exemption has little variation across states, we use the dollar value.

An additional dummy variable equals one if the relevant state allows home purchase and home improvement lenders to collect deficiency judgments against debtors who default on their mortgages. This variable is predicted to be negatively related to credit denials. ${ }^{22}$

Our basic specification is a linear probability model explaining whether applicants for loans were turned down for home purchase (home improvement) loans as a function of the exemption levels and other variables. ${ }^{23}$ Two important econometric issues are (1) whether bankruptcy exemption levels might be endogenous and (2) whether 1992-97 is a long enough time period to

\footnotetext{
${ }^{21}$ There are sometimes other limitations on homestead exemptions, such as maximum acreage limitations. See White [21] and B-H [2] for discussion.

${ }^{22}$ Only five states, California, Minnesota, Montana, North Carolina, and Washington, prohibit deficiency judgments. The data sources for the legal variables are Elias et al. [8] and Leonard [15, p. $7 / 6$ and Appendix].

${ }^{23}$ The results are virtually identical using probit or logit rather than OLS.
} 
allow us to test the model's predictions using only changes in exemption levels, rather than variations across states in exemption levels.

Consider the endogeneity issue first. The U.S. Congress adopted a new Bankruptcy Code in 1978 which specified uniform Federal bankruptcy exemptions that were applicable all over the United States. But the Code allowed states to opt out of the uniform exemptions by adopting their own exemptions and, within a few years, all 50 states had done so. Since the early 1980s, the pattern has been that only a few states change their exemption levels each year and these changes mainly involve correcting nominal dollar amounts for inflation. From 1992 to 1997, states changed their homestead exemptions 11 times and changed their personal property exemptions 10 times. Many of these changes were very small. In addition, the Federal bankruptcy exemption was raised in 1994 and this raised exemption levels in six states that allow their residents to use the Federal exemption. See Table 2. The fact that few states change their exemption levels each year suggests that individual states' bankruptcy exemptions can be treated as exogenous in the model of credit denials.

Now consider the issue of using levels versus changes in bankruptcy exemptions as explanatory variables. Gropp et al. [12] used cross-section data from 1983 to test whether differences in exemption levels across states affect access to credit and they found significant effects. However, cross-section results are vulnerable to criticism because the exemption variables may be acting as proxies for nonbankruptcy variables at the state level which are omitted from the regression. The usual response to this problem in the program evaluation literature has been to use pooled cross-section or panel data-rather than single year cross-section data - and to introduce both state and year fixed effects. B-H followed this approach in their study. But suppose counterfactually that no changes in bankruptcy exemption levels occurred between 1992 and 1997. In that case the bankruptcy exemption variables and the vector of state dummy variables would be perfectly correlated and both could not be used simultaneously. ${ }^{24}$ In this case, pooled cross-section data would tell us no more than cross-section data for a single year. Now suppose a few states changed their exemption levels between 1992 and 1997. Then if we use pooled cross-section data and introduce state dummy variables into the estimation, the state dummies will capture the effect of variation across states in exemption levels, while the exemption variables themselves will capture only the effects of changes in exemption levels between 1992 and 1997. Since only a few changes in exemption levels actually occurred over the period, this specification makes it very unlikely that the exemption variables will be statistically significant.

\footnotetext{
${ }^{24}$ In our model, the exemption variables would actually differ from the state dummy variables depending on whether the state allows doubling of exemptions by married couples who file for bankruptcy.
} 
TABLE 2

State Bankruptcy Exemptions Homestead exemptions
in 1992

$\$ 8000-\$ 30,000$

$\$ 40,000-\$ 100,000$

Unlimited

State
Alabama, Connecticut, Delaware, District of Columbia, Georgia, Kentucky, Illinois, Indiana, Maine, Maryland, Michigan, New Jersey, Ohio, Pennsylvania, Rhode Island, South Carolina, Tennessee, Virginia, West Virginia

Colorado, Hawaii, Louisiana, Missouri, Nebraska, New Hampshire, New Mexico, New York, North Carolina, Oregon, Utah, Vermont, Washington, Wyoming,

Alaska, Arizona, California, Massachusetts, Mississippi, Idaho, Montana, North Dakota, Nevada, Wisconsin

Arkansas, Florida, Iowa, Kansas, Minnesota, Oklahoma, South Dakota, Texas

\section{Personal property exemptions in 1992}

Arizona, Arkansas, Colorado, Delaware, Georgia, Hawaii, Idaho, Maine, Massachusetts, Missouri, Montana, Nebraska, Nevada, New Hampshire, Ohio, Utah, West Virginia

\$2000-\$4500 Alabama, Alaska, California, Florida, Illinois, Indiana, Kentucky, Minnesota, New Mexico, New York, Oklahoma, South Dakota, Tennessee, Washington, Wisconsin, Wyoming \$5000-\$8700 Connecticut, District of Columbia, Iowa, Louisiana, Maryland, Michigan, New Jersey, North Carolina, North Dakota, Oregon, Pennsylvania, Rhode Island, South Carolina $>=\$ 10,000$

\begin{tabular}{lc}
\hline Changes in 1993 & State \\
\hline Homestead exemptions & CT (from $\$ 7,500$ to $\$ 75,000), \mathrm{NM}$ (from $\$ 20,000$ to $\$ 30,000)$, \\
OR (from $\$ 15,000$ to $\$ 25,000)$ & MN (from $\$ 3000$ to $\$ 3200)$, MO (from $\$ 1750$ to $\$ 2250)$, \\
$\begin{array}{c}\text { Personal property } \\
\text { exemptions }\end{array}$ & OR (from $\$ 8700$ to $\$ 9200)$ \\
\hline
\end{tabular}

Exemptions affected by the federal change in 1994

State

DC, MI, NJ, PA, RI, SC (from $\$ 7500$ to $\$ 15,000$ for homestead exemptions, and from $\$ 5350$ to $\$ 10,700$ for personal property exemptions)

\begin{tabular}{ll}
\hline Changes in 1995 & \multicolumn{1}{c}{ State } \\
\hline $\begin{array}{l}\text { Homestead exemptions } \\
\begin{array}{l}\text { Personal property } \\
\text { exemptions }\end{array}\end{array}$ & ME (from \$7500 to \$12,500), VT (from \$30,000 to \$75,000), \\
\hline
\end{tabular}


TABLE 2-Continued

\begin{tabular}{|c|c|}
\hline Changes in 1996 & State \\
\hline Homestead exemptions & MN (from unlimited to $\$ 200,000$ ) \\
\hline $\begin{array}{l}\text { Personal property } \\
\text { exemptions }\end{array}$ & CA (from $\$ 2500$ to $\$ 5000)$ \\
\hline Changes in 1997 & State \\
\hline Homestead exemptions & $\begin{array}{l}\text { MT (from } \$ 40,000 \text { to } \$ 60,000) \text {, NE (from } \$ 10,000 \text { to } \$ 12,500 \text { ), } \\
\text { NV (from } \$ 95,000 \text { to } \$ 125,000) \text {, UT (from } \$ 8000 \text { to } \$ 10,000 \text { ), } \\
\text { WV (from } \$ 7500 \text { to } \$ 15,000 \text { ) }\end{array}$ \\
\hline $\begin{array}{r}\text { Personal property } \\
\text { exemptions }\end{array}$ & $\begin{array}{l}\text { NE (from } \$ 1500 \text { to } \$ 2400), \mathrm{NV} \text { (from } \$ 1500 \text { to } \$ 4500) \text {, } \\
\text { UT (from } \$ 1500 \text { to } \$ 2500) \text {, WV (from } \$ 1600 \text { to } \$ 3200 \text { ), } \\
\text { WY (from } \$ 2000 \text { to } \$ 2400 \text { ) }\end{array}$ \\
\hline
\end{tabular}

But, surprisingly, B-H found a negative and significant relationship between the homestead exemption and the probability of credit denial. They also found a positive but insignificant relationship between the personal property exemption and the probability of credit denial. We report results using both approaches. ${ }^{25}$

\section{RESULTS}

Table 3 shows summary statistics. ${ }^{26}$ The average rejection rate for home improvement loan applications is much higher than that for home purchase loans-30\% versus $15 \%$. Also applicants for home improvement loans have lower incomes and live in census tracts with lower housing values than applicants for home purchase loans. The higher rejection rate for home improvement loans is not surprising. Because home purchase loans carry lower interest rates, households have an incentive to use them to finance both their home purchases and their home improvements. Only less credit-worthy households are forced to use home improvement loans at all. (See Jones [13, 14]). The median homestead exemption is about $\$ 30,000$ and the average personal property exemption is about $\$ 5000$ in both samples. About $20 \%$ of applicants in both samples live in states with unlimited homestead exemptions.

${ }^{25}$ If we regress exemption levels for each state from 1992 to 1997 on a constant term and state dummy variables using OLS, then the $R^{2}$ of the regression is 0.9889 for homestead exemptions and 0.9779 for personal property exemptions. These high $R^{2}$ values illustrate the difficulty of relying exclusively on changes in exemption levels over time to establish whether bankruptcy exemptions affect credit denials.

${ }^{26}$ We use weights to adjust our sample to the number of mortgage applications by state in 1995 . 
TABLE 3

Summary Statistics

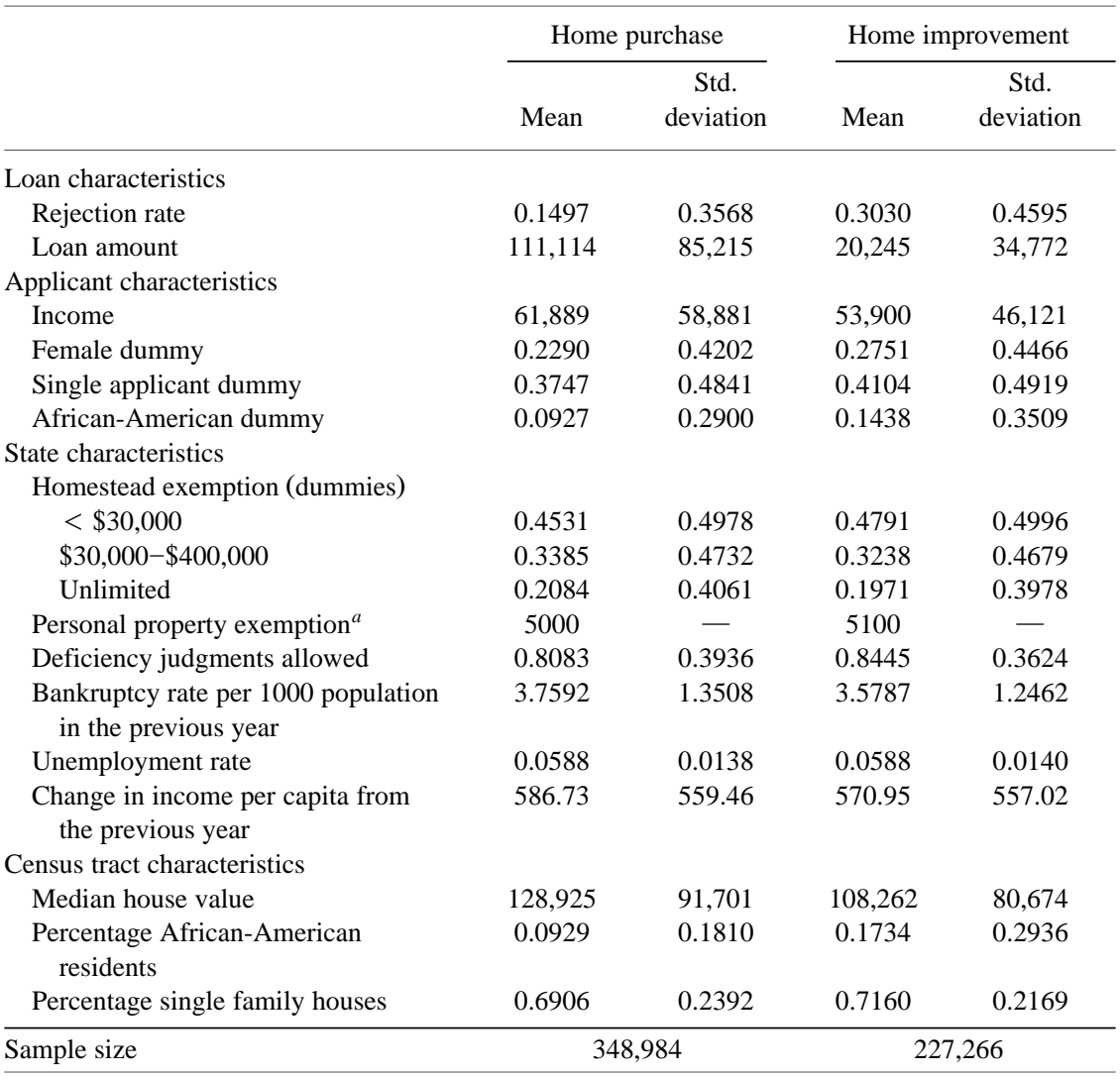

${ }^{a}$ Median value.

In Table 4, we report the results of running a linear probability model explaining whether applicants were turned down for home purchase or home improvement loans. Year fixed effects are included but not state fixed effects. Robust standard errors, which correct for within state/year dependence, are given (see Greene [11, pp. 503-505).

All of the exemption variables have positive signs, for both types of loans. In the home purchase loan model, the personal property exemption and the unlimited homestead exemption variables are both significant at the $1 \%$ level and, in the home improvement loan model, the third category and unlimited homestead exemption variables are both significant at the $1 \%$ level. The large and highly significant coefficients for the unlimited homestead exemption 
TABLE 4

Linear Probability Model of Credit Denial

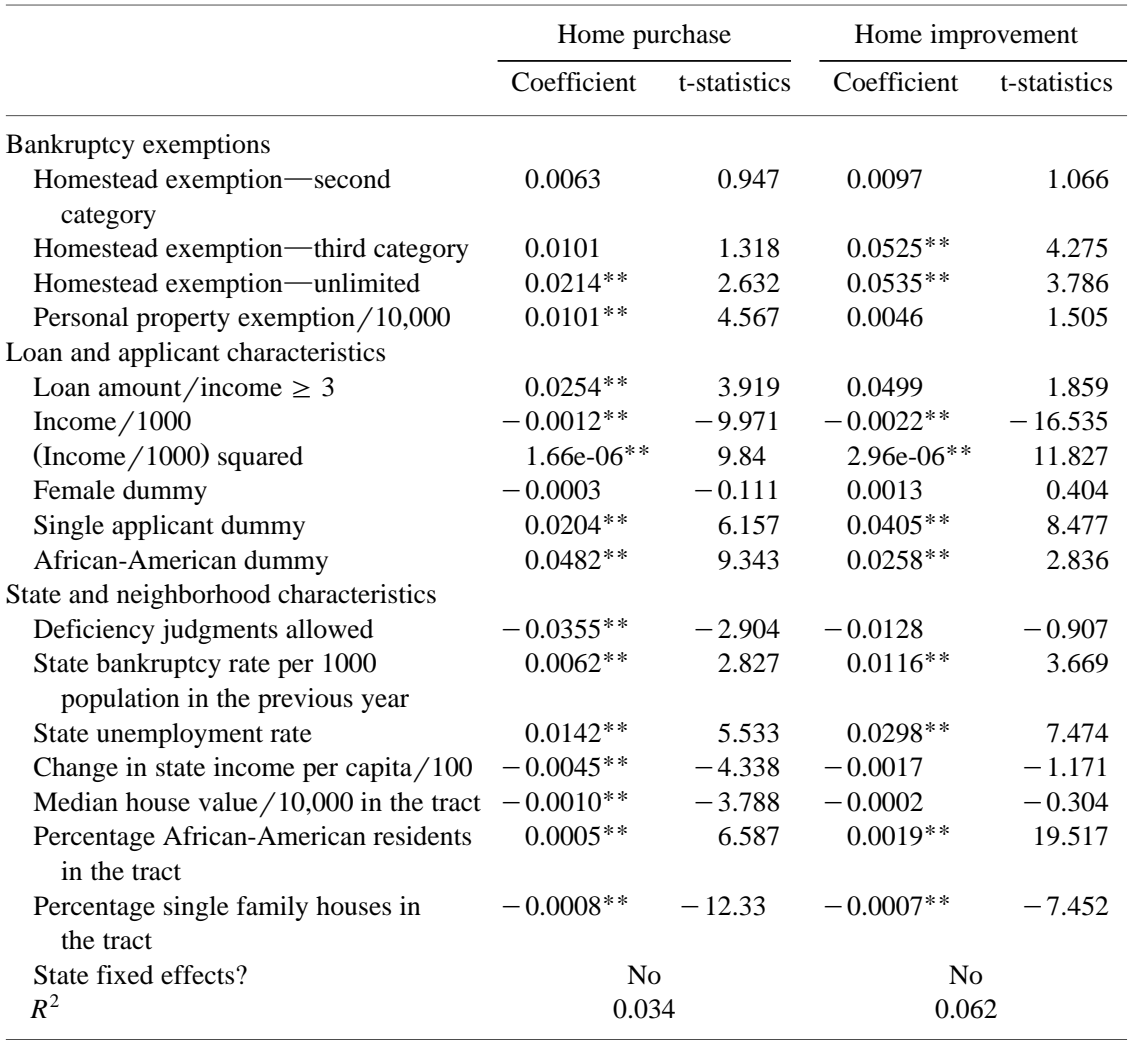

Notes. Regressions include a constant and year dummies. The t-statistics are based on White standard errors and allow for dependence within each state-year cluster.

*Significant at the $5 \%$ level.

**Significant at the $1 \%$ level.

dummies support the theoretical hypothesis that lenders are more likely to choose credit rationing rather than interest rate increases when exemption levels are high. The personal property exemption variable is just short of statistical significance at the $10 \%$ level in the home improvement loan model. The coefficient of the state bankruptcy filing rate in the previous year is also positive as expected and statistically significant at the $1 \%$ level in both regressions.

Other results in Table 4 are reasonable. Applicants with higher incomes are less likely to be turned down for loans, although the effect diminishes as income rises. Single applicants and African-American applicants are signifi- 
cantly more likely to be turned down for both types of loans. ${ }^{27}$ Applicants who live in or plan to live in neighborhoods with more single family homes or in neighborhoods with fewer African-American residents are significantly less likely to be turned down for loans of both types, but the effects are small. Applicants who live in states with higher unemployment rates are significantly more likely to be turned down for both types of loans. The dummy variable for high loan/income ratio is positive in both regressions and significant in the home purchase loan regression. Applicants who live in states that allow deficiency judgments are less likely to be turned down for both types of loans, but the relationship is only significant for home purchase loans.

Table 5 gives predicted probabilities of being turned down for credit, evaluated at the mean values of the variables. If an applicant lives in a state with a homestead exemption of $\$ 7500$, the applicant's probability of being turned down for a home purchase loan is 0.141 , but it rises to 0.151 if the applicant instead lives in a state with a homestead exemption of $\$ 75,000$ and to 0.162 if the homestead exemption is unlimited, respectively. If an applicant with the same characteristics applies for a home improvement loan, then the probabilities of being turned down are 0.277 in a state with a homestead exemption of $\$ 7500$ and 0.331 in a state with a homestead exemption of $\$ 75,000$ or unlimited. The fact that the marginal effect of an increase in the homestead exemption on the probability of being turned down is larger for home purchase loans than for home improvement loans is consistent with applicants for home improvement loans being less credit-worthy based on unobserved characteristics (since we hold constant the effect of observed characteristics). If the same applicant lives in a state with a personal property exemption of $\$ 1000$, then his / her probability of being turned down for a home purchase loan is 0.140 , but it rises to 0.149 if the exemption increases to $\$ 10,000$. For home improvement loans, the corresponding increase is smaller - from 0.298 to 0.302 . Finally if the applicant lives in the state with the highest rather than the lowest average bankruptcy filing rate (Georgia versus Hawaii), then the probability of being turned down for a home purchase loan is predicted to rise by 4.2 percentage points and the probability of being turned down for a home improvement loan is predicted to rise by nearly 8 percentage points.

We wished to test for whether our dataset of loan applications from residents of large metropolitan areas might be a biased sample of all home purchase and home improvement loan applications. To do so, we constructed a second dataset consisting of all loan applications in 1996 from the smallest metropolitan area in each state or, for states that contain only one metropolitan area, all

\footnotetext{
${ }^{27}$ Other studies have previously found evidence that African-American households are more likely to be turned down for home purchase loans. See Yezer [22] and Munnell et al. [16].
} 
TABLE 5

Predicted Probability of Credit Denial

\begin{tabular}{lcc}
\hline & Home purchase & Home improvement \\
\hline Homestead exemption & & \\
$\quad$ First quarter-median $\$ 7,500$ & 0.1409 & 0.2771 \\
$\quad$ Second quarter-median $\$ 15,000$ & 0.1471 & 0.2868 \\
$\quad$ Third quarter-median $\$ 75,000$ & 0.1510 & 0.3296 \\
$\quad$ Unlimited & 0.1623 & 0.3306 \\
Personal property exemption & 0.1394 & 0.2978 \\
$\quad \$ 1000$ & 0.1485 & 0.3020 \\
$\quad$ \$10,000 & 0.1586 & 0.3066 \\
$\quad$ \$20,000 & & \\
State bankruptcy rate & 0.1324 & 0.2726 \\
$\quad$ Hawaii: $0.097 \%$ & 0.1743 & 0.3516 \\
$\quad$ Georgia: $0.777 \%$ &
\end{tabular}

Notes. Figures are evaluated at mean characteristics.

loan applications from nonmetropolitan areas. ${ }^{28}$ We reran the model in Table 4 using this dataset and the results are reported in Table 6 . The exemption variables again have positive signs, except for the second category homestead exemption in the home improvement loan regression. The unlimited homestead exemption variable and the personal property exemption variables are both statistically significant at the $1 \%$ level in the home purchase loan regression. Thus the results suggest that bankruptcy exemptions are important determinants of credit denial for residents of both large and small metropolitan areas.

In Table 7, we rerun the model from Table 4, both with and without state fixed effects. Because of collinearity between the discrete homestead exemption categories and the state dummy variables, we use a continuous rather than discrete specification for the homestead exemption. The homestead exemption variable equals the dollar value of the exemption and, for states with unlimited homestead exemptions, the value is coded as $\$ 500,000 .{ }^{29}$ We also drop the deficiency judgment variable because it does not change over the time period. The results show that, when state fixed effects are omitted, the homestead exemption variable is positive and statistically significant at the $1 \%$ or $5 \%$ level in both regressions. When state fixed effects are added, the homestead exemption variable remains positive and significant at the $10 \%$ level in the

${ }^{28}$ The District of Columbia is excluded from this dataset, since it is entirely in a single metropolitan area. Note that applicants from small metropolitan areas and rural areas have a higher probability of being turned down for home purchase loans than applicants from large metropolitan areas - the figures are 0.2505 for mortgages and 0.2651 for home improvement loans.

${ }^{29}$ The figure exceeds the largest "limited" homestead exemption in the sample, which is $\$ 200,000$ for singles and $\$ 400,000$ for married couples filing for bankruptcy. 
TABLE 6

Linear Probability Model of Credit Denial: Non-MSAs or Small MSAs

\begin{tabular}{|c|c|c|c|c|}
\hline & \multicolumn{2}{|c|}{ Home purchase } & \multicolumn{2}{|c|}{ Home improvement } \\
\hline & Coefficient & t-statistics & Coefficient & t-statistics \\
\hline \multicolumn{5}{|l|}{ Bankruptcy exemptions } \\
\hline $\begin{array}{l}\text { Homestead exemption一 second } \\
\text { category }\end{array}$ & 0.0055 & 0.306 & -0.0062 & -0.159 \\
\hline Homestead exemption一-third category & 0.0107 & 0.441 & 0.0580 & 1.067 \\
\hline Homestead exemption-unlimited & $0.0527 * *$ & 2.732 & 0.0271 & 0.669 \\
\hline Personal property exemption $/ 10,000$ & $0.0261 * *$ & 8.608 & 0.0150 & 1.637 \\
\hline \multicolumn{5}{|l|}{ Loan and applicant characteristics } \\
\hline Loan amount/income $\geq 3$ & -0.0254 & -1.627 & -0.0530 & -0.499 \\
\hline Income / 1000 & $-0.0034^{* *}$ & -7.388 & $-0.0027 * *$ & -6.712 \\
\hline (Income/1000) squared & $4.83 \mathrm{e}-06^{* *}$ & 6.775 & $3.19 \mathrm{e}-06^{* *}$ & 5.274 \\
\hline Female dummy & $0.0302 *$ & 2.549 & -0.0019 & -0.219 \\
\hline Single applicant dummy & -0.0082 & -0.778 & 0.0093 & 0.594 \\
\hline African-American dummy & $0.1329 * *$ & 6.532 & $0.0721^{*}$ & 2.287 \\
\hline \multicolumn{5}{|l|}{ State and neighborhood characteristics } \\
\hline Deficiency judgments allowed & 0.0012 & 0.047 & -0.0297 & -0.669 \\
\hline $\begin{array}{l}\text { State bankruptcy rate per } 1000 \\
\text { population in the previous year }\end{array}$ & 0.0024 & 0.281 & 0.0100 & 0.648 \\
\hline State unemployment rate & 0.0092 & 0.893 & 0.0047 & 0.242 \\
\hline Change in state income per capita/100 & $-0.0144^{* *}$ & -2.717 & -0.0135 & -1.887 \\
\hline Median house value $/ 10,000$ in the tract & $-0.0039 * *$ & -2.279 & 0.0024 & 0.633 \\
\hline $\begin{array}{l}\text { Percentage African-American residents } \\
\text { in the tract }\end{array}$ & $0.0023^{* *}$ & 4.558 & $0.0017^{*}$ & 2.593 \\
\hline $\begin{array}{l}\text { Percentage single family houses in } \\
\text { the tract }\end{array}$ & $-0.0017^{* *}$ & -5.798 & $-0.0014^{* *}$ & -3.256 \\
\hline State fixed effects? & \multicolumn{2}{|l|}{ No } & \multicolumn{2}{|l|}{ No } \\
\hline$R^{2}$ & \multicolumn{2}{|c|}{0.094} & \multicolumn{2}{|l|}{0.045} \\
\hline Observed denial rate & \multicolumn{2}{|c|}{0.2505} & \multicolumn{2}{|c|}{0.2651} \\
\hline Sample size & \multicolumn{2}{|c|}{100,695} & \multicolumn{2}{|c|}{31,742} \\
\hline
\end{tabular}

Notes. Regressions include a constant. The t-statistics are based on White standard errors and allow for dependence within each state-year cluster.

*Significant at the $5 \%$ level.

** Significant at the $1 \%$ level.

home purchase loan regression and positive and significant at the 5\% level in the home improvement loan regression. The personal property exemption variable is positive in both regressions and significant in the home purchase loan regression without state fixed effects but becomes negative and insignificant in both regressions when state fixed effects are added. These findings suggest that the positive relationship between the homestead exemption and the probability of credit denial holds even when we rely on evidence from changes in exemption levels rather than variation in exemption levels. However, changes 
TABLE 7

Linear Probability Model of Credit Denial: Continuous Homestead Exemptions

\section{Home purchase}

(1)
(2)

$\begin{array}{lr}0.0004^{*} & 0.0011 \\ (2.265) & (1.800) \\ 0.0088^{* *} & -0.0138 \\ (3.890) & (-1.730)\end{array}$

Bankruptcy exemptions

Homestead exemption $/ 10,000$

Personal property exemption $/ 10,000$

Loan and applicant characteristics

Loan amount/income $\geq 3$

Income $/ 1000$

(Income/1000) squared

Female dummy

Single applicant dummy

African-American dummy

State and neighborhood characteristics

$\begin{array}{lcccc}\text { State bankruptcy rate per } & 0.0063^{* *} & -0.0064 & 0.0133^{* *} & -0.0090 \\ 1000 \text { population in the } & (2.647) & (-0.750) & (4.174) & (-0.701) \\ \text { previous year } & & & & \\ \text { State unemployment rate } & 0.0178^{* *} & 0.0129^{*} & 0.0337^{* *} & 0.0015 \\ & (6.374) & (2.382) & (7.685) & (0.278) \\ & -0.0049^{* *} & -0.0024^{* *} & -0.0022 & -0.0014 \\ \text { Change in state income } & (-4.260) & (-3.264) & (-1.360) & (-1.574) \\ \text { per capita/100 } & -0.0005 & -0.0005 & 0.0007 & -0.0030^{* *} \\ \text { Median house value/10,000 } & (-1.882) & (-1.690) & (1.225) & (-5.898) \\ \text { in the tract } & 0.0005^{* *} & 0.0005^{* *} & 0.0018^{* *} & 0.0017^{* *} \\ \text { Percentage African-American } & (6.496) & (7.213) & (18.678) & (17.491) \\ \text { residents in the tract } & -0.0008^{* *} & -0.0008^{* *} & -0.0007^{* *} & -0.0006^{* *} \\ \text { Percentage single family } & (-11.205) & (-13.593) & (-7.705) & (-7.962) \\ \text { houses in the tract } & \mathrm{No} & \mathrm{Yes} & \mathrm{No} & \text { Yes } \\ \text { State fixed effects? } & 0.033 & 0.185 & 0.061 & 0.354 \\ R^{2} & & & & \end{array}$

Notes. Regressions include year dummies. $t$-statistics are in parentheses. The t-statistics are based on White standard errors and allow for dependence within each state-year cluster.

* Significant at the $5 \%$ level.

**Significant at the $1 \%$ level.

in personal property exemption levels over the $1992-97$ period are small, so that the results are inconclusive.

Finally, in order to reproduce B-H's specification of the exemption variables as closely as possible, we reran the model in Table 7, but with unlimited homestead exemptions coded as $\$ 1$ million dollars rather than $\$ 500,000$. 
TABLE 8

Alternative Specifications of the Linear Probability Model of Credit Denial:

Unlimited Homestead Exemptions Set at One Million

\begin{tabular}{|c|c|c|c|c|}
\hline & \multicolumn{2}{|c|}{ Home purchase } & \multicolumn{2}{|c|}{ Home improvement } \\
\hline & (1) & (2) & (3) & (4) \\
\hline \multicolumn{5}{|l|}{ Bankruptcy exemptions } \\
\hline Homestead exemption $/ 10,000$ & $\begin{array}{l}0.0002^{*} \\
(2.126)\end{array}$ & $\begin{array}{c}0.0002 \\
(0.958)\end{array}$ & $\begin{array}{l}0.0005^{* *} \\
(3.983)\end{array}$ & $\begin{array}{l}0.0006^{* *} \\
(3.824)\end{array}$ \\
\hline Personal property exemption $/ 10,000$ & $\begin{array}{l}0.0089^{* *} \\
(3.929)\end{array}$ & $\begin{array}{c}-0.0130 \\
(-1.631)\end{array}$ & $\begin{array}{c}0.0024 \\
(0.848)\end{array}$ & $\begin{array}{c}-0.0004 \\
(-0.039)\end{array}$ \\
\hline State fixed effects? & No & Yes & No & Yes \\
\hline
\end{tabular}

Notes. Regressions include the same controls as Table 7. $t$-statistics are in parentheses. The t-statistics are based on White standard errors and allow for dependence within each state-year cluster.

* Significant at the $5 \%$ level.

** Significant at the $1 \%$ level.

Specifying a linear relationship between the homestead exemption and the probability of credit denial forces the marginal effect to be constant over the entire range and, as the dollar value assigned to the unlimited homestead exemption increases, the marginal effect necessarily becomes smaller in size. ${ }^{30}$ The results for the exemption variables - both with and without state fixed effects - are shown in Table 8. The coefficients of the homestead exemption variable fall in magnitude by half compared to their values in Table 7, but the pattern of statistical significance remains the same. In the results with state fixed effects, the coefficient of the homestead exemption variable is positive and significant in the home improvement loan model and positive but not statistically significant in the home purchase loan model. Thus the differences between our results and those of B-H are not due to differences in coding of the unlimited homestead exemption.

\section{CONCLUSION}

This paper investigates the relationship between bankruptcy exemptions and the availability of credit for home purchase and home improvement loans. Contrary to the claims of Berkowitz and Hynes [2], we argue that theory predicts a positive relationship between both the homestead and personal property exemption levels and the probability of borrowers being denied both mortgage and home improvement loans. We test these predictions empirically, using models both with and without state fixed effects. We find strong and

\footnotetext{
${ }^{30}$ Other differences between our specification and B-H's include slightly different time periods, our use of data from the largest metropolitan areas rather than a random sample from the full dataset, and our addition of census tract variables.
} 
statistically significant support for these hypotheses when evidence from variation in bankruptcy exemption levels is used. We also find support for the hypothesis that lenders are more likely to choose credit rationing over interest rate increases when the exemption level is high. Our results show that, when applicants live in states with homestead exemptions that are unlimited rather than having a value of $\$ 7500$, their probability of being denied a home purchase loan rises by 2 percentage points and their probability of being denied a home improvement loan rises by 5 percentage points. When applicants live in states with personal property exemptions of $\$ 10,000$ rather than $\$ 1000$, their probability of being denied a home purchase loan is predicted to rise by 1 percentage point and their probability of being denied a home improvement loan is predicted to rise by 0.4 percentage point. If otherwise identical applicants live in the state with the highest rather than the lowest aggregate bankruptcy filing rate (Georgia versus Hawaii), their probability of being turned down for a home purchase loan is predicted to rise by 4 percentage points and their probability of being turned down for a home improvement loan is predicted to rise by nearly 8 percentage points. When we introduce state fixed effects and use evidence from changes in bankruptcy exemptions, we again find a positive and statistically significant relationship between the homestead exemption and the probability of applicants being denied mortgage and home improvement loans, although the mortgage loan coefficient is only significant at the $10 \%$ level. But we do not find significant relationships between the personal property exemption and the probability of applicants being denied either type of loan. Because there are few changes in bankruptcy exemption levels in any given year and changes in personal property exemption changes are usually very small, it will require more years of data to definitely determine whether there is a statistically significant relationship between the personal property exemption and the probability of applicants being denied mortgage or home improvement loans.

\section{REFERENCES}

1. B. Adler, B. Polak, and A. Schwartz, Regulating consumer bankruptcy: A theoretical inquiry, Journal of Legal Studies, 29, 585-613 (2000).

2. J. Berkowitz and R. Hynes, Bankruptcy exemptions and the market for mortgage loans, Journal of Law and Economics, 42, 809-830 (1999).

3. D. S. Bizer and P. M. De Marzo, Sequential banking, Journal of Political Economy, 100, 41-61 (1992).

4. J. K. Brueckner, Borrower mobility, adverse selection, and mortgage points, Journal of Financial Intermediation, 3, 416-441 (1994).

5. J. K. Brueckner, Mortgage default with asymmetric information, Journal of Urban Economics, 20, 251-274 (2000). 
6. G. B. Canner and W. Passmore, Residential lending to low-income and minority families: Evidence from the 1992 HMDA data," Federal Reserve Bulletin, 80, 79-108 (1994).

7. D. R. Capozza, D. Kazarian, and T. A. Thomson, Mortgage default in local markets, Real Estate Economics, 25, 631-655 (1997).

8. S. Elias, A. Renauer, and R. Leonard, "How to File for Bankruptcy," Nolo Press, Berkeley, CA (1992 and 1996).

9. W. Fan and M. J. White, "Personal Bankruptcy and the Level of Entrepreneurial Activity," Working Paper 2000-02, Department of Economics, University of Michigan (2000).

10. S. Fay, E. Hurst, and M. J. White, “The Household Bankruptcy Decision,' Working Paper 98-01, Department of Economics, University of Michigan (1998). American Economic Review, in press.

11. W. H. Greene, "Econometric Analysis," 3rd ed., Prentice-Hall, New York (1997).

12. R. Gropp, J. K. Scholz, and M. J. White, Personal bankruptcy and credit supply and demand, Quarterly Journal of Economics, 112, 217-251 (1997).

13. L. D. Jones, The demand for home mortgage debt, Journal of Urban Economics, 33, 10-28 (1993).

14. L. D. Jones, Home mortgage debt financing of nonhousing investments," Journal of Real Estate Finance and Economics, 9, 91-112 (1994).

15. R. Leonard, “Chapter 13 Bankruptcy: Repay Your Debts,'” 3rd ed., Nolo Press, Berkeley, CA (1998).

16. A. Munnell, et al., Mortgage lending in Boston: Interpreting HMDA data, American Economic Review, 86, 25-53 (1996).

17. J. M. Quigley and R. Van Order, Explicit tests of contingent claims models of mortgage default, Journal of Real Estate Finance and Economics, 11, 99-117 (1995).

18. F. S. Steingold, "Legal Guide for Starting and Running a Small Business," Vol. 1, Nolo Press, Berkeley, CA (1999).

19. J. E. Stiglitz and A. Weiss, Credit rationing in markets with imperfect information, American Economic Review, 71, 393-410 (1981).

20. H. J. Wang and M. J. White, An optimal personal bankruptcy system and proposed reforms, Journal of Legal Studies, 39, 255-286 (2000).

21. M. J. White, Why it pays to file for bankruptcy: A critical look at incentives under U.S. bankruptcy laws and a proposal for change, University of Chicago Law Review, 65 (1998).

22. A. M. Yezer (Ed.), "Fair Lending Analysis: A Compendium of Essays on the Use of Statistics," pp. 37-44, American Bankers Association, Washington, DC (1995). 